\author{
Kasongo M. Kapanga \\ Kasongo M. Kapanga is an Associate \\ Professor of French at the University of \\ Richmond, Virginia, USA. His latest \\ research focuses on discursive analyses \\ of African novels and reflections on the \\ imagination of the nation in artistic and \\ literary creations of the Democratic \\ Republic of Congo. \\ E-mail:kkasongo@richmond.edu.

\section{Legitimizing the invented Congolese space: The gaze from within in early Congolese fiction}

\title{
Legitimizing the invented Congolese space: The gaze from within in early Congolese fiction
}

Postcolonial discourses describe colonization as a process of invention to impose the will of a conquering West on "backward" societies. The will to power conjugated with the need for raw materials served as the main catalysts. They put side by side a hegemonic intruder bent on duplicating itself, and a powerless and compliant native unable to react to the blitz of transformations. Hence, the master/slave or father/child relationships that describe the colonial framework. The task is to interrogate these generally accepted assumptions and binary oppositions. Although marginalized, the Congolese native was unwilling to become an object for the colonizer's gaze. In fact, the inability to expel the "invader" did not prevent the creation of legitimacies out of what was precipitously brought in. This mechanism of transformation is perceptible in Paul Lomami Tchibamba's novel Ngando (1948), the object of this study. Ngando's imagined colonial city stands out as a site of contrasts and contradictions. However, the duplicated model shows the "transformability" of the new space into "normalcy" by a subversive native. Key words: Congolese literature, Lomami Tchibamba, Joseph Conrad, Nele Mariam, colonial literature, exotic literature.

\section{Discourses of hegemony and compliance}

Several postcolonial discourses describe colonization as a process of invention, whereby under the false pretense of philanthropy, aimed at imposing the will of a conquering West on non-European societies caught behind the curve of progress (Said, Mudimbe, Glissant, Hall). The will to power, conjugated with the growing need to secure natural resources for accelerating the industrialization of Europe, served as the catalyst for an enterprise that self-assigned a humanitarian objective of discovering, classifying, taming, and ultimately civilizing the new. ${ }^{1}$ It would be redundant here to highlight the gross contradictions built in the colonial ideology because several studies have extensively explored the topic. Nevertheless, to highlight this disconnect between the stated aim and the action taken (colonization), one can mention Joseph Conrad's short story "An outpost of progress" and the Cameroonian filmmaker JeanMarie Teno's The Colonial Misunderstanding (2004). The latter is a documentary film analyzing the evangelization process of the Herero people of Namibia and its long lasting aftermath by German missionaries from the town of Wupperthal. Both describe a chaotic atmosphere generated by the so-called the "White man's burden." 
The paper aims at interrogating generally accepted assumptions from which critical assessments draw their conclusions. In describing the colonial enterprise, the classical model reflects a binary opposition grounded in a power matrix where inequalities and therefore the direction of the discourse would evolve in one anticipated way. It described, on one side, a hegemonic intruder bent on duplicating itself through an intense process of co-optation, and, on the other side, a powerless, or at best, a compliant native unable to react to the blitz of transformations awaiting him/her. Hence, the master/slave or father/child relationships detected in the apprehension of a colonial framework going back to ancient times. In conflict with this widely accepted belief, it is my contention that, although this model reflected what was conceptually the intended finality, the native's reactions did not necessarily follow the planned trajectory.

Even though the colonial subject was marginalized and pressured to comply, he/ she did not let him/herself be turned into an object of contemplation to be deciphered within the appropriated space by the Westerner's or the colonizer's gaze. On the contrary, he/she developed a defensive/offensive mechanism to be tactfully deployed as an instrument, however illusive, to judge and evaluate the newcomer. ${ }^{2}$ The inability to expel the "invader" did not prevent the natives from creating legitimacies out of what was introduced, and in some cases the instruments of his subjugation evolved into an offensive apparatus meant to facilitate selfhood and yield plain freedom. As one can show, this mechanism of transformation is perceptible in Paul Lomami Tchibamba's novels (Ngando suivi de Faire Médicament, 1948 and Ah, Mbongo, 2007). The focus will exclusively be on the first work.

The main argument will evolve in three parts. The first will describe the imagined colonial site as a space of contrasts. The second part will highlight the "transformability" of the native's perception of the new space and the principal values sanctioning the new "normalcy" through anthropological writing. From the elements foisted upon communities, new claims through lived experience become the basis for inclusion or exclusion. The third part will identify elements of contradiction that the native's gaze detected and the impact the new situation had in fostering new ideals, communal objectives, and the optimization of another web of social interactions.

\section{Inhospitable land uncovered}

Throughout history, the thick forest area covering central Africa, the Congo, was deemed inimical to the human mind, and therefore largely described as unusually empty. Several studies and writings have underlined the primeval chaotic space in need of alteration (Herodotus, Henry Stanley, Christopher Miller and Joseph Conrad) or have made a descriptive assessment to denounce the unusual metaphor (for instance the authors Michael Crichton, V. S. Naipaul and John le Carré, or the American news anchors Ted Koppel and Anderson Cooper) of an area standing outside 
normalcy. Of these individuals, none deserves more attention than Stanley and Con$\mathrm{rad}$, two pioneers whose names, deeds, and souvenirs remain closely related to the existence of the Congo as a modern state as much as to the metaphor of chaos that has been construed as inherent to this African nation. The centuries of warnings to avoid contact with Central Africa gave room to a new description of a space in great need of domestication. In the $19^{\text {th }}$ century, almost overnight, it had become a duty for enlightened Europe to bring into the fold this area by destroying as much as possible the barriers that had kept it far behind. Rudyard Kipling's poem “The White Man's Burden" (1899) summarizes this claim of enlightened Europe to take care of African natives or other natives under her wings:

Take up the White Man's burden -

Send forth the best ye breed -

Go bind your sons to exile

To serve your captives' need;

To wait in heavy harness,

On fluttered folk and wild -

Your new-caught, sullen peoples,

Half-devil and half-child.

Take up the White Man's burden -

In patience to abide,

To veil the threat of terror

And check the show of pride;

By open speech and simple,

An hundred times made plain

To seek another's profit,

And work another's gain.

(Kipling 1919: 215-16)

With "half-devil and half-child" creatures, the Congo or the inside, mysterious and impenetrable, was virtually a chaos that needed transformation and rearrangement out of philanthropic necessity for the benefit of both the native and humankind. However, explorers penetrated into the inland and witnessed a reality far removed from ideas of horror upheld by the Western imagination. Occasionally, and this experience gave way to a switch in perception to the extent that the lush landscape was no longer as alienating as it came progressively to be discovered. On Stanley's second journey in the heart of the Congo, the crew of Zanzibari porters, marveled at the extraordinary wealth before their eyes as they sailed on the river, are portrayed as deeply astonished by the display of riches: 
Here we discovered that a valuable forest of gum copal trees commenced, the tops of which were draped with orchilla weed. A general burst of admiration broke out from the lips of the Zanzibaris, who were heard to exclaim: "AAh, friends, this is a rich country! Copal below, and enough orchilla to make many fortunes on the top. There is nothing like this in our country. And just look at the rubber bush!" (Stanley 1885, 2: 97)

When sailing on the Congo, Stanley had discovered a vibrant Atlantic trade outgrowth operating on the river using canoes - a specimen is in the Tervuren Museum - large enough to hold one hundred men in addition to heavy cargo. The Bobangi and the Boloki, two ethnic groups he came across with, had given up fishing to devote themselves to the Atlantic trade with a reasonable degree of success in organizing profitable networks in the Congo basin. The notion of emptiness or terra nullius did no longer make sense since explorers, to their great amazement, found deep into the interior a web of communities of which the majority were bursting with energy and whose agreements, symbolic or otherwise, were eagerly sought after to lay claims to these new lands at the behest of European powers. On that second journey on the Congo, Stanley brought back to Europe four hundred treaties signed by local chiefs (Nelson 1994: 52). Yet, if the interior was not empty, practice lagged behind theory and Europeans acted as if they had docked at a deserted island to which anyone could lay claim: discovering people, renaming them, and re-landscaping the terrain on the natives' behalf. Ambivalence surrounded the judgment about the new lands and their inhabitants: faceless and yet with definite Negroid features; empty and yet suppliers of raw materials; blank and yet a place of countless hues and complexions. Discovery then becomes the threshold marking the initial point from which a center would find its meaning and rearrange the overlays. Writings in the colonial mode became fashionable and desirable thanks to an avid readership hungry for exoticism.

The other writer worth mentioning is Joseph Conrad (1854-1922) whose Heart of Darkness, certainly a kind of colonial text, remains one of the literary works to have generated heated debates on the colonial phenomenon, its dubious ideological foundation, and the issue of alterity. In the novel, the steamer Le Roi des Belges turns into an exploratory vessel that allows Marlow to relay to his audience what his sight discovers, experiences, and comes across. The landscape his eyes uncover unfolds and displays the abrasiveness of the primal existence. Sailing upstream the big river turns into a slow discovery of anti-human scenery that blurs vision and disables other senses with the brutalities of the world's dawn: "The reaches opened before us and closed behind, as if the forest had stepped leisurely across the water to bar the way for our return. We penetrated deeper and deeper into the heart of darkness. It was very quiet there." (Conrad 1995: 62) The voyage became a gliding trek into a process of erasure that not only drowns the senses, but cancels the trajectory of measurable time. 
It was a denial of any type of experience/knowledge to the extent that the raw surrounding clouded the comprehension of the world as known then, thus triggering a backwards voyage into the "night of first ages, of those ages that are gone," but still conspicuous in this unsoiled land (Conrad 1995: 62). The march towards progress should proceed unimpeded through a transformative performance of the space. The spatial archetype to allow salvation relies on several poles among which a Christian mission, that is, a site that brings a new order in space, social hierarchy, and epistemology. Now, claims of absence of order called for or induced the outside gaze to formulate a new agenda and a system of dispensation. The perception of the city is one that will emerge out of the colonial foundation while casting the shadow on earlier values, operational processes, and claimed ownership.

\section{From exoticism to the anthropological appeal}

The period after the Reprise/End of World War I (1908 and 1918) during which exotic and colonial literatures flourished, did not display a uniform attitude in the Belgian intellectual circles on the Congo. However, the quasi-unanimous desire to celebrate with national pride overseas goodwill deeds triggered a flood of publications. Literary writings followed the two major trends that not only accompanied colonization as a historical event, but also mimicked the main ideological schools of the time. In spite of their differences, both evolved with a pronounced ethnological desire to probe, grasp, and ultimately control the new dominion. To that effect, Silvia Riva (2004: 23) testifies in her most recent book Nouvelle histoire de la literature du CongoKinshasa as follows: "Since the end of the $19^{\text {th }}$ century, there is a rise of an 'ethnological' literature across the greatest portion of the continent, which, if, on the one hand, allowed the preservation and the salvaging of the most ancient and most popular texts, but also, on the other hand, partially restricted the creative freedom of the first writers." ${ }^{3}$

The same was true on the language level where a tradition to write about the Congo rose both in French and in Dutch. ${ }^{4}$ As it had happened in other colonies mainly the French ones, there was a clear anticipation to see Congolese - especially those educated, write in French to open up their worlds to the outside reader. In principle, even if better knowledge brought changes in the concept about space, the trusteeship was supposed to go only to the enlightened ones - those initiated in the Western know-how - since these tools and epistemological baggage have produced stunning results. Roger Bolamba, Patrice Lumumba, and Paul Lomami Tchibamba would identify themselves with the call. Prior to these pioneers, some voices illustrate the expectation to showcase compliance, or, on the contrary, to display differences. The desire to see the Congolese write their own stories led to two different writing experiences that deserve close attention, namely Nele Marian's poetry and 
Badibanga's L'Éléphant qui marche sur les œufs (The elephant that walks on eggs, 1931). ${ }^{5}$

Nele Marian was a biracial Congolese woman born in Lisala from a Belgian father and a Congolese mother. She lived in the Equateur Province before moving to Belgium where she spent the rest of her life. Up to now, her biographical information still remains sketchy beside her poetry collection discovered in Le Fonds Robert Van Bel at the Documents Center housed at the Bibliothèque Royale Albert I in Brussels. Entitled Poèmes et chansons (Brussels, Ed. De l'Expansion Coloniale, 1935), her poetry collection displays an ideological bent for the natives unusual for her time, an approach that defied the dualistic nature of the colonial society by its use of anti-slavery stand reminiscent of the negritude movement. In reviewing Silvia Riva's book, Vittorio Morabita writes about the poetess: “Her 1935 Poèmes et chansons (Poems and Songs) use a real anti-slavery accent associated with her assertion of her africanness, a move similar to that launched by the negritude movement." ${ }^{\prime 6}$ Marian's biracial status, an asset rather than a liability in the colonial setting, predisposed her to identify with the dominant class that protected children of her background and provided them with better educational opportunities than those reserved for the uneducated black masses. The fact that she bore a European family name is a testimony to her high social standing in a Belgian Congo that unambiguously tolerated a de facto apartheid situation.

At a close examination, Marian's choice through literary engagement to side with the natives in laying claims to her Congolese roots may sound out of place in a Congo where the natives, although considered Belgian subjects, could not enjoy the most basic rights of a citizen. Although thin, her literary themes are rooted in the African landscape nourished by the majestic Grand River as she expresses in the lullaby "Kalinga." Through her poetry, she denounced the oppression exerted against her people as evidenced in "Chanson des Pagayeurs" (The rowers' song):

In the Big river swims a hippotamus

We row

And we send to each shore

A soft refrain of our songs

Because we have to serve a master

We prefer

To endlessly row instead of being

A house servant

(Marian 1935: 32-33) ${ }^{7}$

Despite her privileges, Marian emphatically claims Congo to be her home and Congolese culture her identity foundation. Twenty-five years after the publication of her poetry, despite their excellent education, the few évolués who came along experi- 
enced ambiguity and confusion in the way the relationships between the two countries impacted everyday lives. Bolamba's observations in an article entitled “Les Belges nous ont bien reçus" summarizing his impressions on his first visit to Belgium in 1953 underlines how the colonial situation was awkwardly mired in contradictions:

We always insist on the fusion between Belgium and the Congo. By law, the Congo and Belgium make one state.

We would wish to see Africans given the freedom to travel to the Metropole (Belgium). The fee, which amounts to 50,000 francs, ought to go down. Nothing should prevent Blacks to work in Belgium, it they wish to. The climate is not a plausible reason to reject this demand. Even for university education, Black parents should have the freedom to let their children be educated in Belgian universities of their choice (Bolamba 1953: 698-99). ${ }^{8}$

Although the question about Marian's true thinking remains valid and relevant in trying to find out her mindset, her feelings nevertheless led to express herself in a tone supportive of the Congo's plight, the predicament, and the future. Questions about Badibanga, the author of L'Éléphant qui marche sur les oeufs, remain equally relevant.

As many critics have argued, the identity of Badibanga remains up to these days elusive, and at best an object of hollow speculations. Did Badibanga really exist? If he did, why did he not collect the Médaille Mazarin awarded by the Académie Française? Assuming he existed, did he really write the work that won the prize? Like in Marian's case, would it be legitimate to ask whether the name hides a highly motivated individual or an entire organization standing for a cause? ${ }^{9}$ As many Luba names such as Kasongo, Kazadi, Mujinga, Kabongo, Kabamba, Badibanga is very popular in the Congo. In an anosmatic twist, the choice of such a common name could point to the communal character of the tale, thus inferring collective responsibility rather than individual authorship to assess creativity. Whether it is Tervuren, or an international colonial exposition, or a fictional piece or otherwise, the period between the two World Wars witnessed a burning desire to give proof of a humane treatment to the natives in contrast to the cruelty recorded in the early days of L'État Indépendant $d u$ Congo. Therefore, in a self-serving way, the obsession may show the urge by the Belgian authorities to introduce Congolese culture and intellectuals to the larger public in Europe as testimony to the ongoing success of the l'œuvre. It puts in a marriage of convenience African cultures and Anthropological centers with in between interested parties such as missionaries and colonial administrators. As illustration, the Æquatoria Research Center at Bomanya near Mbandanka, founded in 1937 by two Catholic missionaries, Edmond Boelaert (1899-1966) and Gustaaf Hulstaert (1900-1990), was entirely devoted to the meticulous study of the peoples of the Congo Basin. ${ }^{10}$ 
Badibanga and L'Éléphant qui marche sur les ceufs served as a line of defense through ostensible results - a crowned work - of the major colonial policies enacted in the trail of the Congo Affair. In a large framework, it does not matter who the real author was. What deserves attention is the eagerness to showcase the performing native to testify to the validity of the colonial enterprise's objectives. The name of Badibanga translates the colonial desire of duplicating cultural elements to prove to the main mission. What one may refer to as the Badibanga persona is symptomatic of the ruse of the colonial project in which the Hegelian thesis master/slave was subverted with the invitation of the slave by the master as Stuart Hall (1996: 29) puts it: "to eat at his master's table." Parallel to the efforts to bring to the fore anthropological texts there rose a series of publications in local languages and in French designed for a growing educated audience who needed guidance and Christian pastoral care. La Bibliothèque de l'Étoile founded by the Jesuit priest Carméliau, created several pamphlets targeting educated Congolese readers. Among these, Albert Gérard mentions easy read religious ones entitled Lumière et vie (Light and life), Beaux-Métiers (Beautiful trades), and Étoile (Star) (1986: 168).

The same objective accounts for other shadow authors behind whom labored pens held, not by Congolese individuals, but by Belgian subjects among whom missionaries. The Jesuit priest Albert Leysbeth is rumored to have authored books under the penname of Louis Mabiala - three naïve novels leaning heavily toward didacticism and religious morality propaganda - and also under the European sounding name of Félix Miller (Gérard 1986: 168). In the same way, a close analysis shows that anthropological writings evolved in three different directions determined by the political and social context of the writer. First, they followed a subservient path reflective of the colonial project to showcase native culture and subsequently highlight the progress registered over time. Secondly, they attempted through several linguistic devices to produce ambiguous assessments questioning the main ideology. The third direction evolved as an independent activity that appropriated a Western medium to produce a counter-discourse to affirm the newness of the citizen's subjectivity. As it had happened earlier in other colonies, there was a clear anticipation to see Congolese, especially those educated, write in French, and by the same token open up their worlds to the outside reader.

\section{Claims of the urbanized space: Tchibamba's Ngando (1948)}

Ngando marks a new era that goes beyond the anthropological interest in claiming ownership of the newly transformed society. It is at this juncture that Paul Lomami Tchibamba stands, at a location where Franz Fanon, in writing about national culture, situates the retelling of old stories - here pre-colonial Congo - within the confines of present temporality: "The storyteller who used to relate inert episodes now brings 
them alive and introduces in them modifications which are increasingly fundamental" (Fanon 1953: 240-41, my emphasis). Naming the past as reminiscent of the colonial or even the present conditions raises highbrows on the assumption that it brings forth some anachronisms discordant with the moment. However, in a context of lacks and wants, linking epochs in such an apparently contrived way is a strategy to evoke the future in "recalling and reanimating a certain past" (Radhakrishnan 2008: 107). Consequently, the attempt turns into a dialectical process that ultimately switches the terms by historicizing the present. Ngando (1948), a Mongo tale transcribed in French, constitutes a landmark of the early writings by native authors during the colonial times. ${ }^{11}$

The retelling of the Ngando myth within a context heavily determined by the arrival of the Western culture inaugurates an area of $c o$-existence of two elements in a framework of new conditions and constraints. Kinshasa becomes a world whose heartbeat does not only rhyme to the tune of the African beat, but also to several material, cultural, or ideological elements that now define the urbanized space from within and from without along a series of registers such as a new economic order, trade, culture, and other identification attributes. In this sense, Ngando, the new tale, is inscribed in this ambivalent framework determined by the encounter between Africa and Europe. Within this re-appropriation, lay several main elements worth examining, such as the lingering of the colonial duality, the native's claim to the transformed space, the domination of a monetary economy as the only path to progress, and a new grid of social interactions. Kinshasa stands out as a space bursting at the seams with the new trade and commercial activities. In linking Europe and the African hinterland through the majestic corridor that the Congo River constitutes, it acts as the main node that metaphorically regulates the mood of interaction and the degree of success between these two partners thrown into a marriage of convenience.

Kinshasa or Léo was the urban space par excellence where the duplication of Europe with all its varying facets had to take shape as the ultimate validation of the common task that brought solace and light to the newly discovered lands. Ngando's Kinshasa evolved from a hamlet into a roaring commercial center that the economic prowess makes a strategic foothold linking up Europe, the metropole, and the Congolese wilderness, the coveted land for its mineral and agricultural resources. The "retold" tale foregrounds a city of Kinshasa that completely fits the description of a subservient relay in a grand economic scheme meant to expand Europe's economic capacity at the expense of the newly discovered land. The vital abundance characteristic of the port of "Kinshasa" gives full justification to the colonial operation launched initially as a humanitarian assistance to save scores of humans beings fallen victims to greed, ignorance, and fraternal warfare. The city was not only the launching pad into the inimical inland, but also the gateway to its many facets, shades, and dimensions of things hidden in nature's thickness, therefore undisclosed to Europe's rescuing eyes. 
At first, the traditional hamlet or trade-post undergoes a radical transformation. The split between the new center and the traditional space becomes progressively established as the recent facet grows into a mboka ya mindele (the land of white people, Tchibamba 1982: 27). Secondly, old European rivalries are revived/duplicated at least between France and Belgium over the Mbamu Island (29). Fundamental communication remains vitalized by the metaphorical link "Congolia" that joins both cities on the Big River. Abundance and vitality create a relaxed atmosphere of this nascent port city by foreshadowing vast economic dividends from the site:

Here, in this port, lie as if many elephants taking a rest, piles and piles of bags of corn, peanuts, copal, rubber, sorghum, millet, rice, and especially palm oil nuts, coming from the inside of Africa; everything covered in large waterproofed batches, was waiting to be shipped to Europe, the white man's country, this dream country for the African person and from where come so good and beautiful things; against all these things, there were several boxes of all sizes, also covered in water proof batches, waiting to be shipped to High Congo, the heart of this "incognita land," the land of troglodytes, who today, because of the Great Belgian Monarch, Leopold II, properly channelled Europe's wild interest into the land (Tchibamba 1982: 43-44). ${ }^{12}$

Kinshasa as an invented space marked by the colonial intent of differentiation, duplicating, and co-optation carried within itself the dualistic pulse that underlies the colonial ideology. This is rooted less in the nature of relationships between individuals and community - kinship, friendship, and association - than in one's position and attitude towards what the civilization mission entails. The world consists of two complementary and yet distinctive parts: the Europeans and the Africans.

The interaction between the two groups occurs within parameters heavily determined by the position on the labor scale if you were a native, and on the economic class - here the line between class and race is blurred. Bato ya belesi, or the people from Belgium, acquired legitimacy as those who have appropriated the space (Tchibamba 1982: 47). Political and economic clout derived directly from racial identification collapsed into one single privilege no one could easily disentangle. In other words, residing within the city limits was undoubtedly construed in ontological terms. The alterization of the native, although apprehended in terms of location, was almost exclusively legitimized in racial characterization. The creation of a stratified society under way would evolve according to the economic basis with the requirement that all Congolese, willingly or not, had to contribute to the bustling trade or else be forced to return to their villages, a space that was gradually receding in value in this new labor-gauged configuration. Natives deemed unproductive - jobless, retired, loitering males - were simply denied their presence within the city walls, therefore systematically driven out by merciless periodic police raids: 
Everyone who would be caught loitering should expect to see a policeman springing unexpectedly to request for his working permit, that is, his "work card" delivered by a European employer testifying that the individual was not "jobless." To live in Kinshasa and be unemployed were essentially two things inconsistent with security. Old workers themselves were not spared: worn out, they too were "without a job," their stay pass was withdrawn and they were taken back to their village of origin which, quite often, did no longer exist. (Tchibamba 1982: 46) 13 $^{13}$

The city dweller, therefore, acquired a new valorization gauged in terms of his presence on the scale of productivity to the new economic environment of exploitation, storing, shipping, without any objective in sight for local improvement unless imbricated with the far away land of the Great King. Obviously, as Marxian analysis would perceive it, the alienation of the worker planted the seeds of dissention and ultimately revolt.

However, the scheme of power did not find silent compliance from the natives. Rather, whether in a conspicuous or subdued fashion, the straight jacket into which the colonized was invited to sit could not remain unshaken because of intense resistance from those situated inside. Even the colonial discourse does indeed recognize the stiff fight put up by those wrongly perceived as compliant, childish, and easily credulous. What it failed to see are the various strategies deployed to counteract the original intention to tame and to co-opt, but witnessed instead attempts to subvert the master's plan and to incorporate it within one's own new valorization system. Wrongly, colonial authorities dismissed such reluctance as mere tantrums that could not alter the parameters of the colonial society. In this instance, Nietzsche would detect a clear existence of ressentiment likely to catapult the slave morality to the forefront. As illustration, the admission by Pierre Ryckmans in his narrative Barabara (The road, 1947) of a spying apparatus by the natives set up collectively to warn off fellow villagers of the arrival of the white man on horseback reveals the battle of the wits and its tactical complexities. The latter's abrupt appearance in a village was much feared because of the heavy demands and difficult-to-manage chores piled on the natives and loosely justified as taxes. Ryckmans' comments show that no-one was duped and the mutual mistrust was not a child game:

There was a that time quite some noise in the banana trees every time a caravan would pass. Scouts would announce while he was still afar. Villagers would leave the huts as if running away from an invasion; for a few hours, they would go and occupy the tops of the hill until the last load and the last weapon had disappeared at the horizon. Only, I, too, loved to occupy the tops of a hill. (Ryckmans 1991: 44). ${ }^{16}$

Against the rural background where the native fears the white man, his horse's noise, or his other magical instruments such as a motorcycle, Ngando dramatizes the new 
citizen bent upon claiming as his the new urban space. If the initial intent was to set up an apartheid-like structure, lived experience nevertheless made the narrator come to an awareness/consciousness to claim Kinshasa as a space shared in common with others, foes or friends alike can live within the walls of this city.

The new citizen lays claim to Kinshasa by denying the dualistic condition imposed on the community, but decides through lived experience to let them stand side by side despite the dangers of pitfalls. As Fanon mentions, national culture, within the confines of a new community under the domination of the colonial project, undergoes ruptures and continuities towards the erection of a new paradigm, except this time arising from a subversive counter-attack. The transformation is warranted by the agential intervention headed by the natives with the establishment through various adjustments, authentifications, and creations to legitimize their own temporality. The narrator's intentionality consists in deconstructing from within the main tenets of the colonial assumption both ontologically and locationally - Kinshasa belongs to me too. Situated at the borderline between the traditional and the modern, there is clear awareness of the ambivalence of the location and the exclusive new claims grounded in the historicity of the past and the immanence of the present. ${ }^{17}$ Simultaneously, the colonial figure is symbolically expelled from the property on the ground of the revived past and culture. The new citizen, induced into a reflective mode by contradictory elements in the discourse, progressively questions his/her role in the colonial order. Ngando clearly underlies this refusal as follows:

We are still at that time where our fathers, not quite yet sure of themselves, started nevertheless to believe that the European is not a spirit, but rather a being normally constituted, as other people, although with this unhappy circumstance that the European, that is, the white man, does not believe in our truths and despises our motifs, our mores and customs that we inherited from times past, from earlier times when the first muntu type (human being) appeared on earth (Tchibamba 1982: 26). ${ }^{18}$

Likewise, the refusal to submit to obsequious demeanor acknowledging the native's inferiority runs into a major obstacle expressed in clear terms in the following passage, which incidentally foretells of a war between, on the one hand, the powerless colonizers, and, on the other hand, powerful spirits taking the defense of the natives:

In the skies, Monama would launch a battle to iron birds in which White people cruise in the skies. And when we would manage to defeat whites, it would be quite easy to regain our place in the veneration and the respect of Blacks. From now on, it is the declaration of war against White people (Tchibamba 1982: 68). ${ }^{19}$

The subaltern's dream, although a substitution of a steady campaign of resistance, often indicates a persistent desire to pursue it. Can the subaltern speak for himself? In 
this case, one may say yes, because he has learned to do it from the master. In a reversal of fates and in relying on his own rights, the native finally acts in a way that his "native-ness" becomes the basis of ownership and trusteeships of the transformed space.

\section{Conclusion}

In conclusion, in spite of the self-confidence expressed, it is clear that clouds of doubt persist and the question of agency and intentionality in traditional tales allows serious interrogations. It appears that the native's agency was a reflection of positionality with the emerging of a group of intellectuals immersed both in traditional and in the newly created culture heavily influenced by Western education. Relying on traditional events of the past, the group adopts, after adjustments, criteria of differentiation, which unexpectedly maintain the duality that animated the colonial project. However, one also realizes that the subaltern and the hegemonic are mutually exclusive, leaving thus a third path to representation that is alterity: lived life discloses its richness. A new basis for claims has thus taken shape and form, launching a period to establish the foundation of legitimacy, to proclaim fallacies, and to launch campaigns for one's own defense/ appropriation.

\section{Notes}

1 The four statues in the Tervuren Museum's Rotonda summarise the four-fold cornerstone mission: civilization, security, welfare (le bien-être), and liberation from slavery.

2 René Maran's novel Batouala (1921) served as an example in depicting the native in a realistic way far removed from the expected clichés of colonial and exotic writings of the early $20^{\text {th }}$ century.

3 "Dès la fin du XIXe siècle, on assiste donc, comme sur une grande partie du continent, à l'essor d'une littérature ethnographique qui, si elle a d'un côté permis la conservation et la sauvegarde des textes plus anciens et populaires, et aussi partiellement bridé la liberté créative des premiers écrivains." (23)

4 In my work, I extensively mention Belgian colonial works in French. A similar body of literary writings in Dutch emerged concurrently and did evolve in the same direction. Among some of the best known works: Pieter Danco's Ook een ideaal (Also an ideal, 1896) and Jan Schoup's Blanke Boeien (White schackles, 1934). For more information, see Luc Renders' presentation "In Black and White: An Overview of Dutch Literature in the Congo" delivered at the University of Hasselt conference in July 2008. The Congo topos is still an ongoing interest of the Belgian society. In addition, the first publication by the first Congolese Catholic priest, Stefano Kaoze had a clear ethnological bent: La Psychologie du Bantu (1910).

5 Much has been said or written about these works especially in relation to their real authors. In this project, the interest lies rather in their position in articulating common ideals that reflect the awareness of the population to belong to a national entity.

6 "Ses Poèmes et chansons, utilisent un vrai accent anti-esclavagiste, associé à l'affermissement de l'africanité, semblable en cela à l'appel lancé par le mouvement de la Négritude."(Vittorio Morabita,)

7 Sur le grand fleuve un hippo nage / Nous pagayons / Et lançons vers chaque rivage / Le doux refrain de nos chansons // Puisqu'il nous faut servir un maître / Nous préférons / Ramer sans fin libres, que d'être / Un serviteur dans sa maison. (Mariam, 1935 : 32-33)

8 Nous insistons toujours sur la future fusion belgo-congolaise. Juridiquement, le Congo et la Belgique forment un état. 
Nous voudrions qu'on en arrive à laisser aux Africains la liberté de se rendre dans la Métropole belge. La caution qui est de 50.000 francs devrait être allégée. Rien n'empêche que les Noirs travaillent, s'ils l'entendent bien, en Belgique. L'acclimatation n'est pas un motif plausible pour rejeter notre assertion. Même pour l'enseignement universitaire, les parents noirs devraient avoir la latitude de confier l'instruction de leurs enfants aux universités belges de leur choix. (Bolamba 1953: 698-99)

Also, rent in a Kinshasa cité indigène for a house built by the O.C.A. (Office des Cités Africaines) stood between 300 and 450 francs a month. The price for a house with a little more comfort was below 50,000 francs. See Moulaert (1956: 107).

9 François Bontinck in Badibanga, singulier ou pluriel? (146-70) asks the same question with the implication that it might have taken more than one person to produce this work. Is the author fictious as his own tale? A happy coincidence reinforcing the mystery is related to the meaning of the name Badibanga which in Ciluba (L32 \& L33) simply translates as a simple question: "How many are there/they?" Could Gaston-Denys Périer and Georges Thury who wrote the preface be the real authors of the tale?

10 The first article of the initial issue by G. Hulstaert is on a local language entitled "Considérations sur l'orthographe du lonkundo-lomongo." The center is still operational and can be accessed at http:/ /www.aequatoria.be/

11 His newer novel $A h$ ! Mbongo has been published posthumously and edited by the writer Alain Mabanckou, a native of Congo-Brazzaville, from a manuscript that the author never submitted for publication but found after his death.

12 Ici, au port, comme de nombreux pachydermes en repos, des rangées et des rangées de sacs de maïs, d'arachides, de copal, de caoutchouc, de sorgho, de millet, de riz, d'amandes palmistes surtout, venus de l'intérieur de l'Afrique, le tout couvert de larges bâches imperméables, attendait le départ pour l'Europe, pays de l'homme blanc, ce pays de rêve pour l'Africain et d'où nous viennent tant de si belles et bonnes choses; tout contre ces produits s'alignaient de nombreuses caisses de toutes dimensions, également bâchées, attendant leur départ pour le Haut-Congo, le cœur de cette "terre incognita", pays des troglodytes, qui aujourd'hui, grâce au Grand Monarque Belge, Léopold II, aiguillonnait la convoitise du monde européen intéressé. (Tchibamba 1982: 4344)

13 Tout homme qui y flânait devait s'attendre à voir surgir d'un moment à l'autre devant lui un policier qui lui réclamait sa mokanda ya mosala, c'est-à-dire sa "carte de travail" délivrée par un employeur européen attestant que l'intéressé n'était pas "sans travail." Habiter Kinshasa et être chômeur étaient deux choses incompatibles avec la sécurité. Les vieux travailleurs eux-mêmes n'étaient pas épargnés : usés, ils étaient aussi des "sans travail"; l'autorisation des séjours leur était retirée et on les refoulait dans leur village d'origine qui, souvent, n'existait plus. (Tchibamba 1982: 46)

14 Fanon linking resistance to the burst of violence finds here its foundation.

15 Allusion is here made to Nietzsche's essay "On the Genealogy of Morals" (1887).

16 Il y avait à cette époque grand branle-bas dans les bananeraies quand passait une caravane. Les guetteurs l'annonçaient au loin. On évacuait les huttes comme devant une invasion; on allait s'installer pour quelques heures sur les crêtes voisines, jusqu'à ce que le dernier ballot et le dernier fusil eussent disparu à l'horizon. Seulement moi aussi je préférais les crêtes. (Ryckmans 1991: 44)

17 Like the American "Pledge of Allegiance", the narrator tersely and clearly asserts ownership and trusteeship to "this land," "my land."

18 Nous sommes à cette époque où nos pères, encore mal assurés, commençaient néanmoins à se convaincre que l'Européen n'est pas un élima, mais bien un homme normalement constitué, comme tous les autres hommes, avec cette malheureuse circonstance que l'Européen, c'est-à-dire l'homme blanc, ne croit pas à nos vérités et dénigre nos motifs, nos usages et nos coutumes qui nous viennent pourtant de très loin à travers les âges passés, du premier temps où le premier homme du type bantu a commence son existence sur la terre. (Tchibamba 1982: 26)

19 Dans les airs, Monama livrera combat aux oiseaux de fer avec lesquels les Blancs sillonnent nos cieux. Et lorsque nous parviendrons à vaincre les Blancs, il nous sera tout à fait facile de regagner notre place dans la vénération et dans la crainte des Noirs. A partir d'aujourd'hui, c'est la guerre déclarée contre les Blancs! (Tchibamba 1982: 68) 


\section{Works cited}

Bolamba, Antoine-Roger. 1953. Les Belges nous ont bien reçus. La Revue Coloniale Belge 191: 698-99.

Bontinck, François. 1992. Badibanga, singulier ou pluriel?" Papier blanc, encre noir: Cent ans de culture francophone en Afrique centrale. In Marc Quaghebeur, Emile Van Balberghe, Annick Vilain, Nadine Fettweis (eds). 2 vols. Bruxelles: Labor: 146-70.

Conrad, Joseph. 1995 [1898]. Heart of Darkness. London: Penguin.

Fanon, Frantz. 1963. The Wretched of the World. New York: Grove Press.

Gérard, Albert. 1986. European-language Writing in Sub-Saharan Africa: A Comparative History of Literatures in European Languages. Budapest: Akademiai Kiado.

Hall, Stuart. 1996. After-Life of Franz Fanon. Why Fanon? Why Now? Why Black Skin Why Mask? In Alan Read (ed). The Fact of Blackness Frantz Fanon and Visual Representation. Seattle: Institute of International Visual Arts Bay, 12-37.

Hulstaert, G. [O]. Considérations sur l'orthographe du lonkundo-lomongo. <http://www.aequatoria.be/> Accessed: 01.11.2008

Kipling, Rudyard. 1919. Collected Verse of Rudyard Kipling. New York \& Garden City: Doubleday.

Morabito, Vittorio. 2003 [O]. Rev. of Rulli di tam-tam dalla torre di Babele. Storia della letteratura del Congo-Kinshasa, by Silvia Riva. Cahiers d'études africaines, 172. < http://etudesafricaines.revues.org/ document1557.html> Accessed: 10.09.2008.

Moulaert, G. 1956. Le Logement des travailleurs indigènes. La Revue Coloniale Belge, 249 (février): 107-10.

Muswaswa, Bertin Makolo. 1995. La poésie zaïroise. In Pierre Halen and János Riesz (eds.). Littérature du Congo-Zaïre. Amsterdam \& Atlanta: Matatu, 51-83.

Nelson, Samuel H. 1994. Colonialism in the Congo Basin: 1880-1940, Athens, Ohio: Ohio University Center for International Studies.

Radhakrishnan, R. 2008. History, the Human, and the World Between, Durham, N.C.: Duke University Press.

Riva, Silvia. 2004. Nouvelle histoire de la littérature du Congo-Kinshasa. Paris: L'harmattan.

Ryckmans, Pierre. 1991 [1947]. Barabara. Lubumbashi, R.D.C: Impala.

Stanley, Henry M. 1885. The Congo and the Founding of Its Free State. New York: Harper.

Tchibamba, Paul Lomami. 1982 [1948]. Ngando suivi de Faire Médicament. Kinshasa: Présence Africaine, Édition Lokole. 